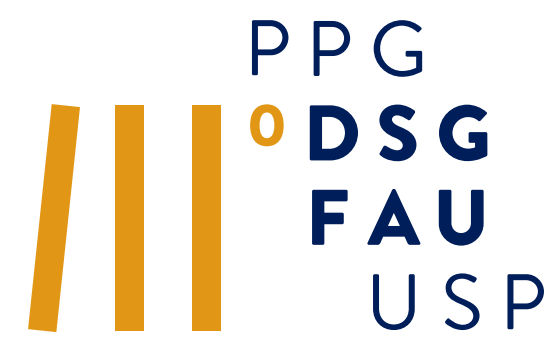

ANDRÉ DEAK

\section{GISELLE BEIGUELIMAN}

NÍVEL DE PESQUISA

RESEARCH LEVEL

DOUTORADO

DOCTORATE

\section{ANDRÉ DEAK}

André Deak é doutorando em Design na FAU-USP. Diretor do Liquid Media Lab, produtor de jornalismo multimídia, consultor de comunicação digital, professor na graduação da ESPM, pesquisador do Laboratório para Outros Urbanismos e do LabCidade da FAU. Trabalha desde 1998 com projetos para jornalismo e comunicação na internet.

André Deak is a PhD student in Design at FAU-USP. Director of Liquid Media Lab, producer of multimedia journalism, digital communication consultant, undergraduate professor at ESPM, researcher at the Laboratory for Other Urbanism and FAC LabCidade. He has been working since 1998 with projects for journalism and internet communication.

andredeak@gmail.com

lattes.cnpq.br/

0434558072616306

\section{GISELLE BEIGUELMAN}

Professora Associada nos cursos de Arquitetura e Urbanismo e Design da Universidade de São Paulo. É artista e suas pesquisas abordam: intervenções artísticas com mídias digitais no espaço público; preservação de arte digital; arte e ativismo em rede; estéticas da memória no séc. 21.

Associate Professor of Architecture and Urbanism and Design at the University of São Paulo. She is an artist and her research interests include: artistic interventions in the public space with digital media; preservation of digital art; art and activism in the network; 21 st century aesthetic memory

gbeiguelman@usp.br

lattes.cnpq.br/

4120752125995822

\title{
CIDADES INTELIGENTES, UTOPIAS TECNOLÓGICAS: O NOVO DESIGN DA COLONIZAÇÃO
}

\author{
SMART CITIES, TECHNOLOGICAL UTOPIAS: THE NEW DESIGN \\ OF COLONIZATION
}

\author{
PALAVRAS-CHAVE: SMART CITIES, BIG DATA, ESTADO PLATAFORMA, COLONIALISMO \\ DIGITAL, DECOLONIALISMO
}

\section{KEYWORDS: SMART CITIES, BIG DATA, PLATFORM STATE, DIGITAL COLONIALISM, DECOLONIALISM}

A ideia de cidades inteligentes tem gerado uma miragem de consumo em que o planejamento urbano é esvaziado em nome de um produto. O próprio conceito tem caminhado para se tornar algo desejado, mas impossível de ser definido. Essa construção conceitual serve bem aos vendedores de tecnologia, como aponta Greenfield (2013). Tem similaridades com o tecnoutopismo presente no início da internet e hoje atualizado como uma nova forma de colonização digital (COULDRY \& MEJIAS, 2019). Diferentemente do modernismo, no entanto, não são mais os arquitetos e urbanistas, mas os programadores de algoritmos que propõem cidades melhores para um futuro utópico. O modernismo já mostrou não ser possível pensar cidades a partir de uma tábula rasa, sem levar em conta a matéria prima de toda civilização: a cultura e a memória. A apropriação que os brasileiros fizeram da ideia modernista completará 100 anos em 2022, e talvez possa servir para investigar o que seria, então, uma smart cityantropofágica, voltada para melhorar a democracia e criar futuros a partir de outras perspectivas. A hipótese é que cidades que não utilizem em sua concepção tecnológica princípios e design do Sul Global, com elementos de códigos abertos, ética hacker, teorias do commons,serão apenas mais uma ferramenta para ampliar o abismo social, uma face do colonialismo digital que serve aos Estados Plataforma (BRATTON, 2015). Os excluídos, para além de não-consumidores, seriam também os que sequer servem para produzir dados - invisíveis assim aos olhos do sistema, e portanto a toda forma de serviços públicos. Não-cidadãos, não-existentes. $O$ estudo faz por fim um levantamento de alguns exemplos de usos e tecnologias que subvertem as lógicas de colonização e servem como ferramentas de cidadania, em vez de controle.

The idea of smart cities has generated a consumption mirage in which urban planning is emptied in the name of a product. The concept itself has been moving towards becoming something desired, but impossible to define. This conceptual construction serves technology sellers well, as Greenfield (2013) points out. It has similarities with the techno-utopianism present in the beginning of the internet and today updated as a new form of digital colonization (COULDRY \& MEJIAS, 2019). Unlike modernism, however, it is no longer architects and urban planners, but algorithm programmers who propose better cities for a utopian future. Modernism has already shown that it is not possible to think of cities based on a blank slate, without taking into account the raw material of all civilization: culture and memory. The appropriation that Brazilians made of the modernist idea will complete 100 years in 2022, and perhaps it can serve to investigate what would be, then, an anthropophagic smart city, aimed at improving democracy and creating futures from other perspectives. The hypothesis is that cities that do not use in their technological conception principles and design of the Global South, with elements of open codes, hacker ethics, theories of commons, will be just another tool to widen the social abyss, a face of digital colonialism that serves to the Platform States (BRATTON, 2015). The excluded, in addition to being non-consumers, would also be those who do not even serve to produce data - thus invisible to the eyes of the system, and therefore to all forms of public services. Non-citizens, non-existent. The study finally makes a survey of some examples of uses and technologies that subvert the logic of colonization and serve as tools of citizenship, instead of control. 